\title{
WAGES, UNEMPLOYMENT, AND GLOBALIZATION: A TALE OF CONVENTIONAL WISDOMS
}

\author{
Oliver Landmann \\ Institut für Allgemeine Wirtschaftsforschung, Universität Freiburg, \\ 79085 Freiburg, Germany (e-mail: landmann@vwl.uni-freiburg.de)
}

\section{Introduction}

The widespread fear of globalization - "globaphobia" as Burtless et al. (1998) have termed it - may have several sources. But the most immediate concern of most people surely is what globalization has done or will do to their prospects on the labor market. Interestingly, this is true even for the United States where unemployment has steadily been falling over the past years to its lowest level in decades. But at the same time, US real wages have increased very slowly for more than two decades, and at the bottom end of the wage ladder, the rate of change of real incomes has even been negative. In Europe, in contrast, it is the intractable problem of high and persistent unemployment that forms the backdrop to the globalization debate. Here too, the least skilled workers are hit worst. The common concern on both sides of the Atlantic is that globalization might depress labor incomes, increase income inequality and thus eventually turn out to be a social time bomb.

Why suddenly these worries after several decades of steady trade liberalisation and increasing global integration that are generally hailed as a major force sustaining the historically high growth rates of the post-war era? True, there was a marked slowdown of economic growth in the early 1970s, i.e. around the time that is often identified with the beginning of the modern globalization era. If something began to change at that time, it was the structure of world trade and the scope for global movements of capital. Whereas the spectacular expansion of world trade in the immediate post-war period was largely confined to intra-

\footnotetext{
' Valuable comments by my discussant Arne Heise and other conference participants as well as by Michael Pflüger are gratefully acknowledged. Klaus Veigel helped with the figures and the layout.
} 
industry trade among the advanced industrial economies, the early 1970s marked the beginning of the equally spectacular rise of some newly industrializing, mostly Asian economies as significant producers and exporters of manufactured goods. Soon, these economies also attracted relatively large amounts of foreign direct investments and other forms of capital.

This emerging North-South trade differed from the still dominant North-North trade in that it was largely inter-industry trade, based on differential factor endowments - the South deriving its comparative advantage from its large supplies of cheap, but potentially efficient labor. This explains the worries that give rise to "globaphobia“: If globalization means that producers and workers worldwide are increasingly required to compete on globally integrated markets, how can it be that the abundant supply of cheap labor in low-wage countries does not pose a major threat to jobs and wages in the advanced countries? Among many politicians and in the public at large, perceptions of globalization are strongly shaped by concerns of such immediate intuitive appeal.

The globalization debate has sparked an outburst of academic research as well, again with a heavy emphasis on the implications for the labor market. This new research blended with and added to the earlier research efforts devoted to the explanation of wage behavior and employment in the industrial economies. In particular, the globalization issue heightened the challenge of providing a convincing and coherent account of the sharp differences between labor market developments in the USA and in Europe. These differences are the subject of popular views so widely shared that they attained the status of conventional wisdoms. In particular, they involve propositions concerning, on the one hand, a trade-off between real wage growth and employment growth and, on the other hand, a trade-off between inequality and unemployment.

The present paper cannot attempt to do justice to the huge theoretical and empirical literature dealing with the effects of globalization on wages and employment. A few remarks in section 5 will have to suffice. Rather, its aim is to place the current concerns about globalization into the context of the earlier conventional wisdoms. To this purpose, section 2 briefly summarizes the substance and factual background of the conventional wisdoms while the subsequent sections take up the underlying theoretical ideas: Sections 3 adresses the alleged trade-off between the wage level and unemployment, section 4 explains how globalization could pose a trade-off between wage inequality and unemployment and how the two trade-offs could be related. Section 6 concludes. 


\section{Conventional Wisdoms: New and Old}

Much research has recently been devoted to the labor market effects of globalization. If there is anything like a mainstream view emanating from this research, it does not support the notion that globalization is a major factor behind OECD labor market developments. However, it is also fair to say that this mainstream view, and the theoretical and empirical results on which it is based, leave quite a few questions unanswered and, therefore, leave ample room for dissenting views. ${ }^{2}$ While it may be hard to agree on a common interpretation and explanation of the facts, there is little disagreement as to what the facts are. The major stylized facts that frame the debate can be summarized by the following four observations:

1. The share of emerging economies in world exports of manufactured goods has sharply increased since 1970 and is due to increase further in the future. ${ }^{3}$

2. In most advanced countries, changes in the structure of labor demand since at least 1980 have clearly favored skilled labor at the expense of unskilled labor. ${ }^{4}$

3. Wage differentials have markedly widened in the United States and the United Kingdom, but remained largely constant or even narrowed in most continental European economies. ${ }^{5}$ As figure 1 suggests, this is true irrespective of the specific measure of wage dispersion considered. ${ }^{6}$

4. Countries that have avoided the increase in wage inequality have typically experienced rising unemployment rates, in particular among the unskilled (cf. figure $2^{7}$ ).

${ }^{2}$ For recent surveys and debates, see the symposia in the Journal of Economic Perspectives, Vol. 9, No. 3, 1995, and Vol. 12, No. 4, 1998, in The Economic Journal, September 1998, as well as IMF (1997), Collins (1998) and Siebert (forthcoming).

Cf. World Bank (1997).

${ }^{4}$ Cf. Nickell/Bell (1995), Drèze/Sneesens (1997), Blanchard (1997b).

${ }^{5}$ Cf. IMF (1997) and the studies in Freeman/Katz (1995).

${ }^{6}$ Figure 1 is reproduced from Hesse (1998), p. 160

${ }^{7}$ Figure 2 is reproduced from Phelps (1997). 


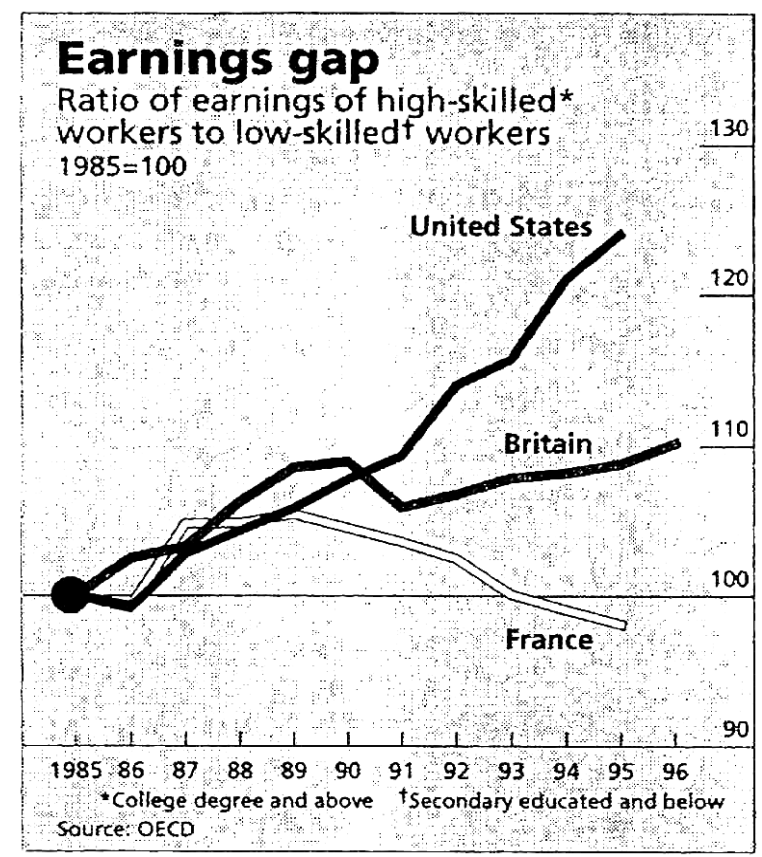

Dispersion of gross earnings, 1979 to 1995: D9/D1 ratio

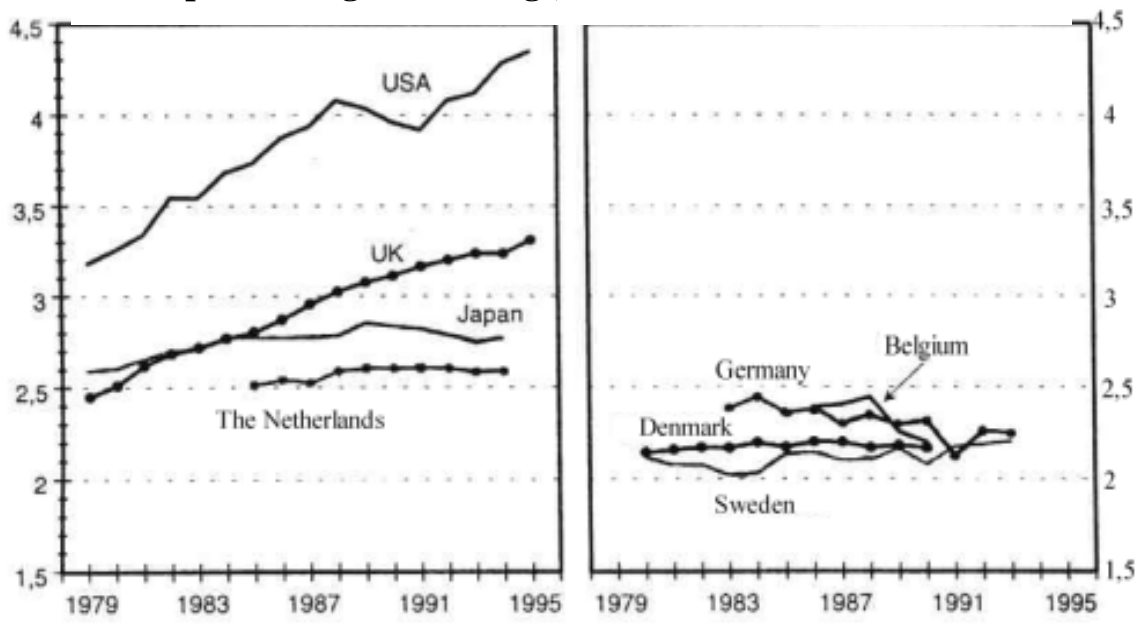

The D1/D9 ratio is the ratio of the lower boundary of the top income decile and the upper boundary of the bottom income decile.

Figure 1: Wage differentials in international perspective

Source: Hesse (1998), p. 160 


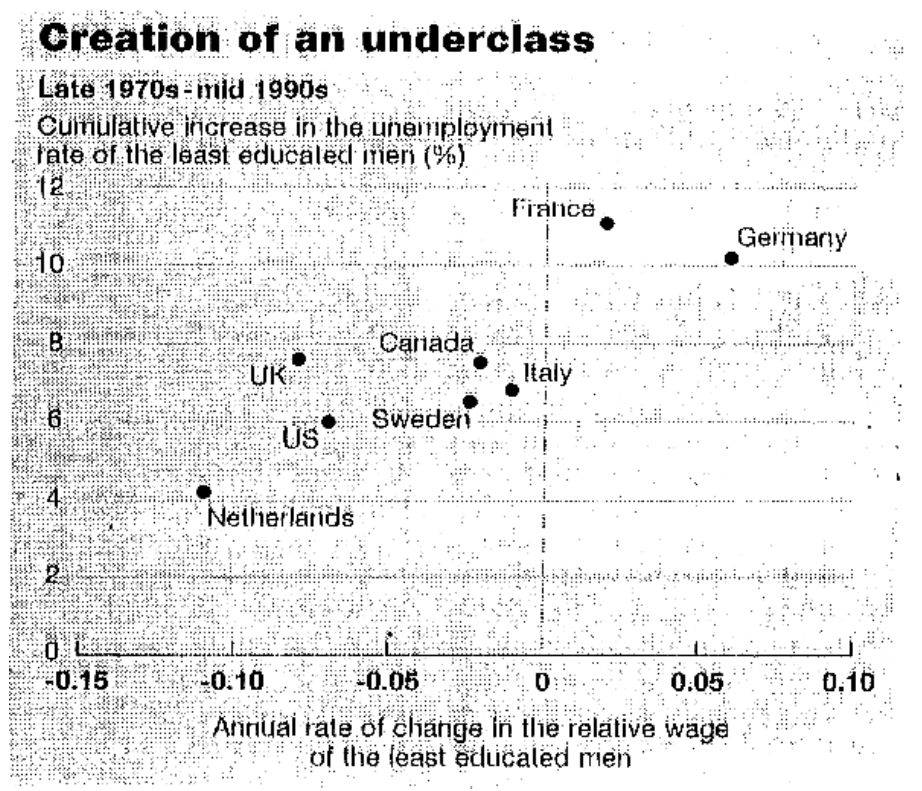

Figure 2: Unskilled wages and employment

Source: Phelps (1997)

Observations 2-4 suggest an interpretation which is so intuitively appealing that it is almost universally accepted as a "Conventional Wisdom" (Krugman 1994): Where labor market institutions are designed to pursue egalitarian goals, they collide with market forces that pull in the opposite direction. This inevitably results in high unemployment rates. Where the determination of the wage structure is left to market forces, in contrast, unemployment can be kept low. The price to be paid for avoiding high unemployment, it seems, is the creation of an underclass of "working poor". In short, there appears to be an unpleasant trade-off between unemployment and wage inequality.

Not too long ago, there used to be another and somewhat different conventional wisdom which was concerned less with the structure of wages than with the absolute level of wages. This older story dates back to the 1970s when the oil price shocks confronted the advanced industrialized economies with yet another dark side of globalization. The suddden increase of the oil price not only imposed a real income loss on oil-importing countries, but also reduced the marginal product of their labor in proportion to their dependency on foreign energy sources. If this exogenous shock was to be absorbed without serious damage to employment, real wages needed to display a fair amount of flexibility. The worldwide productivity slowdown that occurred at about the same time for partly independent reasons placed an additional burden of adjustment on labor markets. As the story goes, the United States was relatively well prepared for this kind of adjustment. To be sure, 
the supply shocks, the ensuing inflation, and the efforts of macroeconomic policymakers to deal with these unexpected disturbances, exposed the US economy to quite some cyclical instability; but this did not visibly affect the unemployment rate in the longer term.

Not so in Europe. In most European countries, the stagflationary effects of the external supply shock were exacerbated by the the refusal of wage setters to share the burden of higher oil prices and to adjust their wage demands sufficiently downwards in response to the productivity slowdown. This real wage resistance, as it came to be called by Sachs (1979) and Bruno/Sachs (1985), translated the adverse shift of the labor demand schedule into higher unemployment. Worse, the external supply shock coincided with a wage explosion which had its roots in the labor unrest of the late 1960s. The resulting cumulation of external and internal cost push provided a ready case study for the concept of classical unemployment which was much en vogue among Europe's academics at that time (cf. Malinvaud 1977).

As it turned out, the insufficient responsiveness of wage setting process to unemployment was a deep-seated feature of European labor markets that continued to prevent a return to full employment ever since - notwithstanding the more than complete reversal of the external supply shocks later on. Looking back on the entire time span since 1970, it is apparent that Europe and the United States experienced sharply differing evolutions of their respective real wage and employment levels. The middle and the bottom panels in figure 3 convey this well known picture.

In its May 1995 World Economic Outlook, from which figure 3 is reproduced, the International Monetary Fund succinctly summarized the conventional wisdom regarding these sharply contrasting labor market experiences in two propositions.' The first proposition is about the factors that are not to blame for Europe's dismal employment performance: Obviously, insufficient demand growth and too low a rate of capital formation are unlikely causes of the unemployment problem. After all, as the two top panels of figure 3 demonstrate, the average growth rates of real GDP and the capital stock have been nearly equal in the United States and in Europe. The second proposition offers an alternative explanation placing less emphasis on the volume of investment than on the type of investment that occurred: Rigid labor markets and excessive wage claims in Europe have encouraged capital-labor substitution (capital deepening) whereas the more flexible US labor market favored employment-generating capacity expansion

\footnotetext{
${ }^{8}$ This instability shows up quite clearly in the unemployment series displayed in figure 3 .
}

${ }^{9}$ See IMF (1995) and the summary in the IMF Survey, July 3, 1995, pp. 212-13. 
(capital widening). As a consequence, Europe experienced relatively strong increases in the capital-labor ratio and in labor productivity which in turn supported the relatively strong real wage performance. However, as the IMF puts it, "the higher real wages benefited a declining share of the European labor force."

The European Union and the United States:

Output, Capital, Employment, and Wages

$(1970=100$, unless noted otherwise $)$
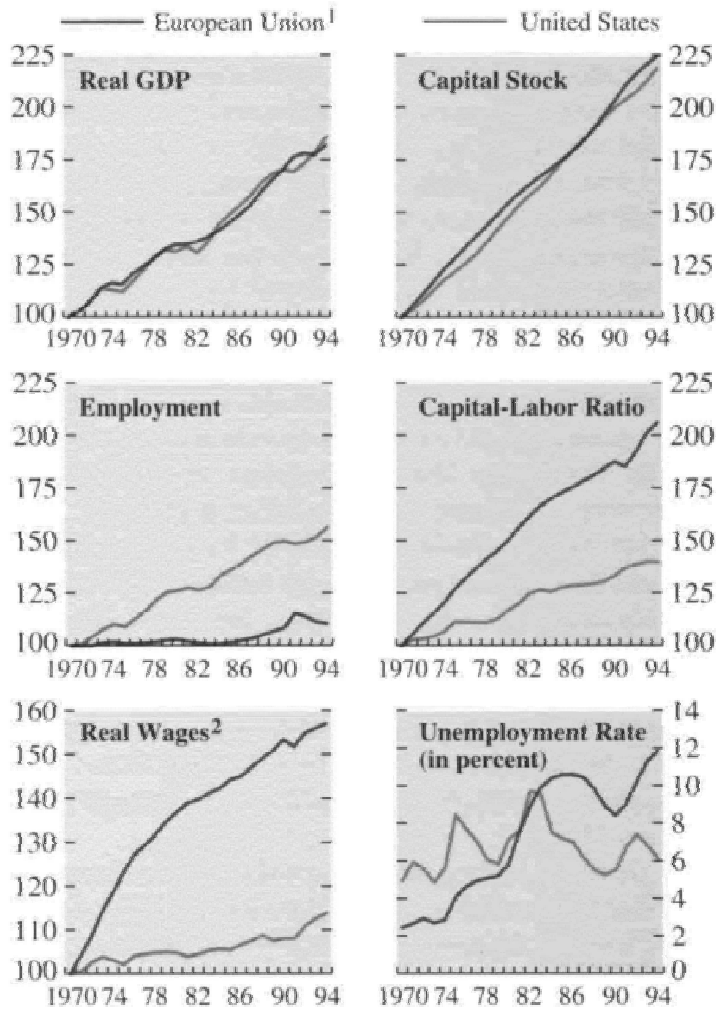

Sources: OECD, analytical data base; and IMF staff estimates.

'Excluding Luxembourg and Portugal. Real GDP, capital stocks, and real wages are calculated using PPP-based weights.

${ }^{2}$ National accounts compensation per employee deflated by the GDP deflator.

Figure 3: Europe vs. The United States, 1970-94

Source:IMF (1995), p. 32 
The two conventional wisdoms do not tell the same story. The more recent conventional wisdom is about the skill intensity of production and the skill premium. It portrays the choice between the American model and the European model as a choice between wage inequality and unemployment. The earlier conventional wisdom is a more traditional story about aggregate employment, the capital-labor ratio, labor productivity, and the general wage level. Here the tradeoff appears to be between extensive and intensive growth or, by implication, between strong employment growth and strong real wage growth. Both conventional wisdoms obviously fit the stylized facts to which they refer. But what are their theoretical foundations? How do they fit together? And how do they relate to globalization? These are the questions to which we turn next.

\section{A Trade-Off Between Unemployment and Real Wages?}

This section takes a closer look at the alleged trade-off between the real wage level and the volume of employment. The notion of such a trade-off is immediately appealing to basic economic intuition since this is essentially the trade-off suggested by the neoclassical labor demand curve of our textbooks. Similarly, it seems plausible that this trade-off is reinforced in the medium run by the response of capital investment to wage behavior. Aggressive wage increases push firms into capital-intensive modes of production and thus make it harder to recover the lost jobs at a later point. It is a trade-off that the United States and Europe, according to the old conventional wisdom, have solved in different ways. Also, it is indisputable that the terms of this trade-off are very much on the mind of politicians as they debate employment and labor market policies. If the only way back to full employment is the creation of US-style wage and productivity stagnation, many Europeans argue, it may not be worth it.

There is just one problem with this point of view: It is in conflict with standard macroeconomic unemployment theory. According to the textbook model of longterm employment determination, there is no such thing as a trade-off between jobs and wages over any extended period of time. The trade-off may exist in a short run for any given production capacity, but as time passes and investment responds, labor demand becomes very elastic. With a constant-returns-to-scale technlogy and a fully endogenous capital stock, the long-run labor demand curve in fact becomes horizontal. ${ }^{10}$ This is not the place to develop the argument in full detail.

${ }^{10}$ See Bean (1989) and Blanchard (1990). Burda (1988) and Landmann/Jerger (1993) develop fully dynamic models of employment and capital stock adjustment. For a textbook 
The important point to realize is that the real wage cannot in a meaningful way be regarded as an exogenous variable in long-run general equilibrium. Hence, it is misleading to treat it as a major determinant of the aggregate capital-labor ratio. If anything, the causation runs the other way round. In the most elementary model of long-run equilibrium, the structure of the relationships that determine employment, the capital stock and the wage level is fully recursive: The long-run capital-labor ratio is uniquely determined by technology and the cost of capital. The real wage, in turn, is a single-valued function of the capital-labor ratio and thus independent of wage-setting behavior. It is in this sense that labor demand is perfectly elastic with respect to the real wage level. All that is left for wage-setting to do is the determination of the equilibrium employment level along the horizontal labor demand function." Given the capital-labor ratio, the absolute capital stock can then be derived as well.

A crucial implication of this account is, of course, that it debunks the notion of a long-run trade-off between the level of real wages and the level of employment. Simple as it may be, the standard model is strongly supported by the observation that European unemployment has remained high or even increased in the face of slowing real wage growth and a declining labor share throughout the 1980s and 1990 s. $^{12}$ While it is true that the supply shocks of the 1970 s initially pushed up both real wages and unemployment, thus pointing to a wage-employment tradeoff, the picture changed as the response of investment to the job losses made itself felt. In an attempt to bring back their capital-labor ratios into line with the requirements of cost minimization, firms cut back their investment spending and thus diminished the scope for further productivity and wage growth. This adjustment was reinforced by the steep rise of real interest rates which occurred worldwide around the year 1980 and warranted a further downward revision of optimal capital-labor ratios. ${ }^{13}$ It is not altogether surprising, therefore, that real wages appear to have been pushed even below their pre-supply-shock baseline path in the process.

treatment, see Landmann/Jerger (1999), Ch. 6. The relevant model is also sketched by Berthold/Fehn (1999) in this volume.

${ }^{11}$ In general, with imperfect competition on the goods market, it is more appropriate to speak of a price-setting function instead of a labor demand function.

${ }^{12}$ Landmann and Jerger (1993) analyze the experience of Germany along these lines. Caballero and Hammour (1997) study the effects of changing labor relations on factor substitution in France. Blanchard (1997a) looks at the recent slide of the labor share throughout continental Europe.

${ }^{13}$ This rise of global interest rates plays a major part in Phelps's (1994) account of what he terms "structural slumps". 
One might be tempted to dismiss this account of events on the grounds that it is inconsistent with the observed behavior of capital-labor ratios which continued to rise throughout Europe even though the relevant theory says they should have been revised downwards in the course of the adjustment process. ${ }^{14}$ However, this observation can seem puzzling only if one neglects the trend increase of capitallabor ratios due to (the labor augmenting component of) technical progress. Having estimated this trend component and after adjusting the time path of Germany's capital-labor ratio accordingly, Landmann/Jerger (1993) find clear evidence for the expected fall of the adjusted capital intensity from 1977 onwards, which accounts for the further slowdown of productivity and real wage growth during the 1980 s as compared to the already low post-1973 rates.

In short, the notion of a long-run trade-off between unemployment and real wages does not stand up to careful theoretical and empirical analysis. Aggressive wage-setting behavior does not accelerate capital-deepening for long nor can it secure sustainable real wage gains for workers. It does set in motion, though, a vicious circle of job losses and capacity destruction feeding upon each other. In the process, the equilibrium unemployment rate is pushed up.

This account might prompt the question of why wage setters push for higher wages at all if they have to be aware that, in the final analysis, all they get is fewer jobs instead of higher wages. There are two answers to this: First, to the extent that wage bargaining takes place in a decentralized way, wage setters play a noncooperative game in which they do not only have a stake in their sector's relative wage, but also, since the aggregate price level is a public good, in their individual real wages. This will become quite clear in the relative wage model of the next section. Second, workers benefit from lags. The horizontal labor demand function is a long-run concept. It takes time for the capital stock to adjust to lower employment and, in the shorter run, it also takes time for the price level to catch up with higher wages. Under these circumstances, simple dynamic optimization principles suggest that it is worthwile to exploit the trade-off while it lasts.

All of which leaves yet another question unanswered: If we indeed believe that differences in wage-setting behavior can explain differences in the long-term evolution of unemployment, and if we also believe that these differences are unrelated to the long-term growth of real wages and capital-labor ratios, how do

\footnotetext{
${ }^{14}$ This observation prompted Caballero/Hammour (1997) to construct a model which reconciles sustained capital-deepening in the face of rising unemployment by the assumption that firms switch to more labor-saving technologies in order to protect themselves from the appropriation attempts of labor. This model has the remarkable property that a wage-setting shock may even lower the real wage level in the long run. However, the model would thereby seem to imply an acceleration of labor-saving technical change, which is the opposite of what is generally found in studies of the well-known 'productivity slowdown'.
} 
we explain the picture conveyed by figure 3 which seems to suggest that the relatively strong real wage growth in Europe is the mirror image of her weak employment performance?

This question is adressed in a recent paper by Gordon (1997) who has couched the trade-off issue in terms of the relationship between unemployment and productivity growth. Of course, long-run real wage growth is closely related to the growth of labor productivity even though the shifts in the labor share indicate that the correlation is not perfect. Gordon's findings strongly support the theoretical presumption that the contrasting unemployment experiences of the USA and Europe have little to do with the differential productivity and real wage patterns. Rather, his productivity growth regressions confirm the insights of the voluminous convergence literature according to which a substantial fraction of the more rapid productivity growth in Europe as compared to the United States is due to catch-up.

It is well known that this convergence of productivity levels, and hence real wage levels, among the advanced industrial nations has been going on over the entire post-war period. In fact, the US-European differential with respect to capital accumulation, productivity growth and real wage growth was significantly larger before 1970 than after. In other words, Europe has experienced a much sharper productivity slowdown than the USA. These already diminished differentials are what we see in the real wage and capital-labor ratio panels of figure 3 .

Also, Gordon's decomposition of labor productivity growth into the respective contributions of capital deepening and total factor productivity growth shows that labor productivity grew more slowly in all major European countries in the 197992 period than during 1973-79 and that slowing capital deepening played a major part in almost every case whereas exactly the opposite happened in the USA. ${ }^{15}$ This finding directly contradicts the IMF's (1995) interpretation of the relative capital-intensity and real wage developments cited in the last section, but it is perfectly consistent with the disinvestment story sketched in this section. The downward revision of European capacity expansion plans in response to sluggish employment growth thus contributed to a further narrowing of the US-European productivity and real wage growth differential throughout the 1980s - in spite of (or rather in line with) the further build-up of the unemployment differential.

In the light of these results, it is hardly surprising that Gordon was unable to detect any significant effect of the change in unemployment in his productivity growth regressions. What he did find, though, were significant coefficients on various sector dummies, indicating substantial productivity growth differentials across sectors. This implies that the aggregate productivity and real wage figures can be strongly affected by changes in the sectoral output mix of an economy. Of

${ }^{15}$ Cf. Gordon (1997, Table 14.2, p. 455). 
course, the sectoral structure of production is at the very core of the theory that underlies the more recent conventional wisdom about the trade-off between unemployment and the dispersion of wages. As the next section takes a closer look at that theory, it will be natural to ask, therefore, whether the effects of relative labor demand shifts that result under alternative assumptions about relative wages can add to our understanding of aggregate wages and aggregate employment.

\section{Globalization, the Structure of Labor Demand, and Relative Wages"}

The interaction of unemployment, productivity, the real wage and capital formation is an inherently macroeconomic story. Apart from external supply shocks and perhaps global interest-rate shocks, this story does not prominently feature international economic linkages, trade and globalization. In contrast, the analysis of relative labor demand shifts, relative wages and the structure of employment requires an explicitly microeconomic framework. And since globalization is a prime suspect in this plot, the natural place to start with is standard general equilibrium trade theory. Much of the theoretical and empirical work on the labor market effects of globalization has indeed been placed into the framework of the HOS (Heckscher-Ohlin-Samuelson) model. As will become clear below, though, there are legitimate concerns that this paradigm might narrow down the issues more than is warranted.

Since the popular concern is with developing or newly industrializing countries that are abundantly endowed with cheap labor and, hence, are positioned to flood the markets of advanced economies with low-wage exports, the standard approach in this literature is to build models of inter-industry North-South trade with two factors of production, skilled labor and unskilled labor. Physical capital is typically left out of the picture. This specification is sometimes justified by reference to perfect international capital mobility which removes rate-of-return differentials as a source of comparative advantage (Wood 1991). With fully endogenous adjustment of capital stocks, the overall capital-labor ratios are determined by exactly the same logic as in the long-run macro model of the preceding section. As a consequence, capital can be lumped together with total factor productivity and relegated to the back-stage as the analysis of relative skill intensities proceeds.

Even if one hesitates to apply the extreme assumption of perfect international capital mobility to real capital, it can legitimately be argued that wage and per-

${ }^{16}$ This section draws freely on Landmann/Pflüger (1996 and 1998). 
capita income disparities between North and South are not easily explained by differences in physical capital-labor ratios. Indeed, if human capital formation is the driving force of economic development, as the work of Lucas (1988) and Romer/Mankiw/Weil (1992) suggests, it appears not too far-fetched to use a skillbased trade model for the analysis of North-South trade.

It is straightforward to derive the implications of such trade for relative labor demand and the structure of employment in the North, depending on whether relative wages are assumed flexible or rigid. The essence of what the HOS model predicts under either assumption is captured by figure $4 .{ }^{17}$ The North produces two goods, a high-tech good $\mathrm{F}$ and a low-tech good $\mathrm{M}$. The factors of production, skilled labor $\mathrm{K}$ and unskilled labor L, earn wages $r$ and $w$, respectively. High-tech production is assumed to be more skill-intensive than low-tech production. The North is depicted as a large, initially closed economy. The pre-globalization state of the world is thus represented by the simplifying assumption that there is no North-South trade at all. As the South enters world trade in manufactured goods, the effects on the North are conditioned by the relative scarcity of skilled labor in the South.

The upper-right panel of figure 4 depicts the goods market equilibrium, with the relative price and the relative quantity of the two goods being shown on the axes. $R D$ is the ratio of Northern consumers' demand for the high-tech good and their demand for the low-tech good. This relative demand curve slopes downward reflecting the usual response of the consumption pattern to changes in the relative price $p_{F} / p_{M}{ }^{18}$ The supply schedule $R S$, in contrast, shows how the production pattern changes as Northern producers move along their production possibilities frontier in response to a relative price change. This schedule is thus derived under the assumption of fully employed factors. ${ }^{19}$ The intersection of $R S$ and $R D$ at point $A$ establishes the autarky equilibrium of the North. The autarky price ratio is given by $\left(\mathrm{p}_{\mathrm{F}} / \mathrm{p}_{\mathrm{M}}\right)_{\mathrm{N}}$.

${ }^{17}$ The figure is reproduced here with minor modifications from Landmann/Pflüger (1998) where all the equations underlying the particular schedules are given in full detail.

${ }^{18}$ Strictly speaking, the unique relationship between relative demand and relative prices requires homothetic utility.

${ }^{19}$ The full employment condition is actually stronger than what is needed. Constant employment rates of both factors would do as well. 




Figure 4: Globalization as seen through the lens of the HOS model

Source: Landmann/Pflüger (1998), p. 134

The factor market implications of the goods market equilibrium are evident from the upper-left and the lower-left panels. The $S$-S schedule in the upper-left panel represents the relationship between the relative goods price $p_{F} / p_{M}$ and the relative factor price $w / r$ spelled out by the Stolper-Samuelson theorem. The factor price ratio, in turn, determines factor intensities in both industries. The factor intensity functions in the lower-left panel reflect the assumption about the comparative factor intensity of the two industries stated above. Evidently, the North remains incompletely specialized as long as its overall factor endowment ratio No remains in the range between $(K / L)_{F}$ and $(K / L)_{M}-$ which is simply assumed here. Finally, the lower-right panel depicts the relationship between $F / M$ and $K / L$ as implied by the Rybczynski theorem for any given factor price ratio. 
What happens when the South enters the market? Being abundantly endowed with unskilled labor, it should be expected to have a comparative advantage in the production of the low-tech good. Northern producers of the low-tech good are thus confronted with a fall in demand due to increasing import penetration, whereas the market for Northern producers of the high-tech good expands. These changes can be summarized by a shift of the relative demand curve from $R D$ to $R D^{\prime}$. With $\left(p_{R} / p_{M}\right)_{S}$ denoting autarky prices in the South, the horizontal distance from $R D$ to $R D^{\prime}$ is a measure of the net trade volumes implied by the Southern offer curve at any given price ratio.

If markets are open and prices flexible, a new equilibrium is established at point $D$. Northern producers and consumers face a higher relative price of the high-tech good as the world market price settles at $\left(p_{P} / p_{M}\right)_{W}$. High-tech production in the North expands at the expense of low-tech production while consumers choose the new consumption point $C$ where they demand relatively more of the now cheaper low-tech-good. The distance $\overline{\mathrm{CD}}$ is related to the volume of NorthSouth trade obtaining in the new situation. It is straightforward to derive the further implications of this trade: According to the Stolper-Samuelson logic, the skill premium goes up, i.e. the factor price ratio $w / r$ falls. As a consequence, the skill intensity in both industries falls as well. The Rybczynski relationship in the lower-right panel shifts to the right so as to reconcile the change in the output mix with the unchanged factor endowment.

The same apparatus can be used to analyze the rigid wage case..$^{20}$ The early literature on the implications of rigid wages in trade models has tended to stipulate some type of real wage rigidity. ${ }^{21}$ However, in view of the ample evidence for rigid wage structures in continental Europe, the assumption of rigid relative wages appears more appropriate to our present purpose.

How does the entry of labor-abundant emerging economies affect a rigid North? If the factor price ratio $w / r$ is not allowed to fall in the face of changing supply and demand conditions, the first immediate implication is that the relative price of the two goods cannot change either. That is, the Samuelson-Stolper theorem cuts both ways - as a mere corollary of profit maximization conditions, it does not require any assumption of flexible factor prices. The economic intuition behind this result is that, for any given c.r.s technology, a constant factor price ratio implies unchanged factor intensities and, therefore, unchanged factor productivities in both industries. Hence, producers face constant marginal costs and are ready to accommodate any demand changes along horizontal supply

${ }^{20}$ The application of the HOS apparatus to the analysis of North-South trade when factor prices are rigid in the North was pioneered by Krugman (1995).

${ }^{21}$ See, in particular, Brecher (1974a,b). 
curves. A first conclusion immediately follows: The factor market rigidity, by suppressing the response of the goods prices, represents a free gift of the North to the South in the sense that the latter gets more favorable terms of trade than would be obtainable with flexible markets.

Under these circumstances, and again assuming open markets, the goods market equilibrium in the upper-right panel of figure 4 moves horizontally from A to $\mathrm{B}$. It is evident from the figure that the rigidity of relative prices amplifies both the extent of structural change, i.e. the adjustment of the output mix $F / M$, and the volume of North-South trade. The latter is determined by the offer curve of the South, given the terms of trade implied by factor prices in the North. Assuming a normally sloped offer curve, the volume of trade is increasing in the relative price of the low-tech good. Also, being pushed by market forces to point B, producers in the North are obviously thrown off their flexible-price supply curve $R S$. This is tantamount to saying that the economy is pushed off its production possibilities frontier. In fact, due to the rigid factor prices, the structure of production does not adjust simply through sectoral reallocation of the factors, but also through adjustments in overall factor use. Instead of moving along its bowed out production possibilities frontier, the economy moves inside the frontier along a straight Rybczynski line (cf. Krugman 1995, Srinivasan 1995).

Just as the factor price rigidity gives rise to a peculiar causal interpretation of the Stolper-Samuelson theorem, the Rybczynski theorem is put to some uncommon use in the present context: Normally seen as a statement about the effect of changing factor supplies on the sectoral structure of output, it serves here to highlight the repercussions of the trade-induced adjustment in the sectoral output mix on effective factor use. This effect is expressed in figure 4 by the movement from A to B along the "Ryb"-schedule in the lower-right panel. Because of the fixed factor price ratio, the position of this schedule is unchanged. As a consequence, the overall $K / L$-ratio of the economy must increase. If we assume that skilled labor is initially fully employed or, more generally, that its employment rate cannot be raised any further, the only way to achieve the required adjustment in $K / L$ is by shedding unskilled labor. The change in $K / L$ from $N o$ to $N o^{\prime}$ thus indicates the amount of unemployment that arises among the unskilled. It is easy to see that the unemployment generated by North-South trade is directly proportional to the volume of that trade, and it is equally straightforward to show (though not immediately within the panels of figure 4) that the factor market distortion turns the potential mutual gains from trade into an absolute real income loss for the North.

As will become clear in the next section, there is considerable controversy about the empirical relevance and importance of these labor market effects of globalization, particularly in comparison to technical change. But regardless of how this controversy might eventually be resolved, there is a lesson in the above analysis that is more general than the specific shock at work: Whatever it is that 
causes the structure of labor demand to change, if relative wages are not allowed to reflect these changes, employment levels will have to carry the burden of adjustment.

There is also scope for disagreement about the relative importance of shocks to the structure of labor demand and shocks to the aggregate level of labor demand. For example, Blanchard (1997b) argues that changes in the composition of unemployment cannot be regarded as discriminating evidence in favor of relative labor demand shifts as opposed to aggregate labor demand shifts or wage-setting shocks. For various reasons - 'ladder' effects, 'ranking' effects, and so on -, even fully symmetric adverse shocks tend to increase unemployment among unskilled workers by much more than among the skilled. But again, there is a more general point worth making: Whatever it is that causes unemployment disproportionally to affect unskilled labor, the asymmetric incidence has important implications for the aggregate summary statistics that are typically used to describe labor market developments. In particular, as low-wage jobs are destroyed (or prevented from being created), the aggregate wage bill suffers less than the aggregate volume of employment. As a consequence, the aggregate real wage level, defined as the ratio of the aggregate wage bill and aggregate employment, rises along with the unemployment rate. Although no individual wage rate needs to have changed, the trade-off between the real wage level and the unemployment rate reappears as an aggregation phenomenon.

The model in figure 4 is well suited to illustrate the point. We only need to compare the two scenarios for the behavior of the North. With flexible wages, the Stolper-Samuelson theorem tells us that the emergence of the South raises the wage of skilled labor and lowers the wage of unskilled labor, not only relative to each other, but also in real terms. The aggregate real income of the two factors must rise due to the gains from trade while their employment rates remain unchanged. With rigid relative wages, both real wage rates are constant, but unskilled employment falls. Hence, per capita income must fall, but if the wage differential between the two types of labor is big enough, the average income per employed can easily rise by much more than it does in the flexible wage scenario.

The relevance of this phenomenon extends beyond the structural adjustments that the model of this section can capture. In particular, the employment prospects of the less-skilled does not just depend on what globalization and technological change do to high-tech and low-tech manufacturing industries, but also very much on the pace of job creation in the nontradables sector. Wage rigidities and regulations can have strong effects on the capacity of the service sector to expand so as to make up for job losses elsewhere in the economy. Clearly, this is an important part of the explanation for the employment growth differential between the United States and Europe. 
It is a popular, though misleading caricature of the American 'employment miracle' to portray it as consisting mainly of low-wage, hamburger-flipping jobs. It is true, however, that the flexibility of the wage structure in the USA has facilitated the absorption of large numbers of low-skilled workers into the employment system ${ }^{22}$ whereas in Europe, high minimum wages and rigid relative wages have kept the number of low-paying jobs low. Again, the macro statistics suggest that the rigidities buy higher average wages and productivity at the cost of lower employment (the trade-off notion of section 3). But again, this does not mean that existing jobs are necessarily better paid on average than they would be in the absence of the rigidities. All it means is that there are fewer poorly paid low-productivity jobs.

This interpretation of the role of the service sector as a potential 'employer of last resort' for unskilled labor is vividly illustrated by Gordon's (1997) comparison of French and US productivity growth in the 1979-92 period. In France, where the minimum wage was set as a high and rising fraction of average hourly compensation, output per hour grew with an annual rate of $2.55 \%$, more than double as fast as in the USA where the minimum wage was a low and rapidly falling fraction of average hourly compensation. But remarkably, productivity growth hardly differed between the two countries in manufacturing: $2.85 \%$ in France as compared to $2.50 \%$ in the USA. The difference rather arises in the nonmanufacturing, non-farm, non-mining sector (i.e. essentially in services and construction) where output per hour grew by a mere $0.63 \%$ p.a. in the USA, less than a third of the French rate. In the same vein, Corrado/Slifman (1999) demonstrate that aggregate productivity statistics for the USA are heavily coloured by compositional effects, with measured (mismeasured?) construction and service sector productivities acting as a drag on the overall productivity performance in the 1977-1997 period.

\section{Open Questions about the Impact of Globalization}

The HOS model presented in the previous section has served as a point of reference for much of the debate on the impact of globalization. But the availability of a neat, well-known model does not mean that globalization is an important factor behind recent labor market developments, or if it is an important factor, it cannot be taken for granted that its effects make themselves felt mainly along the lines suggested by the model. The relevant literature is large and rapidly

\footnotetext{
${ }^{22}$ Cf. Ochel (1998).
} 
growing and this is not the place for a survey. ${ }^{23} \mathrm{~A}$ few remarks shall suffice in this section.

Generally speaking, the literature has proceeded from simple judgements that were based on simple observations to more sophisticated approaches covering a wide array of transmission channels. Much attention has been attracted by disputes over methodology.

As an example of a simple observation cited as support for far-reaching claims about the impact of globalization, figure 5 shows a seemingly strong correlation between the decline in the share of manufacturing employment and the increase in manufactured imports from developing countries for a sample of advanced industrialized countries. This correlation was presented by Wood $(1995$, p. 63) as evidence that North-South trade hurts unskilled labor. To him, the cross-country evidence looks so strong as to "make it hard to believe that trade had only small effects, for if this were so, the association would surely be disguised by other influences."

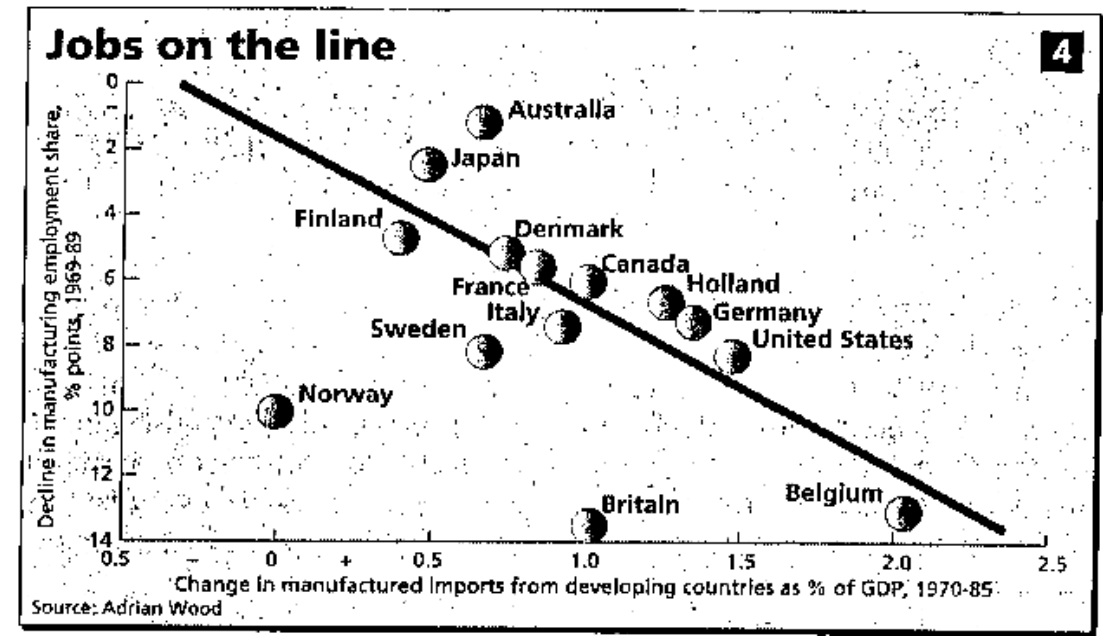

\section{Figure 5: Declining manufacturing employment and import penetration}

Source: The Economist, April 2, 1994

Apart from the fact that the absolute magnitudes along the horizontal axis are exremely small, such correlations always raise questions about causality. While it may be that trade is the forcing variable and manufacturing employment the

${ }^{23}$ Again, the reader is referred to the sources cited in footnote 1, above. 
effect, reverse causation is also possible as Wood himself acknowledges. The model of figure 4, above, can easily be used to show how this could happen. Suppose relative wages are rigid and the gap between skilled and unskilled wages is narrowed, say by a hike in the minimum wage. Obviously, this would force the production of the low-tech good to contract, its relative price to rise and, hence, import penetration to rise as well.

Wood dismisses the possibility of such reverse causation on the grounds that it would imply a positive cross-country correlation between import penetration and the relative wage of the unskilled, which he says is not what we observe. But even this clever argument does not really close the case. Suppose, for example, that there is non-neutral technical change, biased against unskilled labor. This would, by itself, tend to lower the relative wage of unskilled workers. If the political system leans against this tendency by increasing the minimum wage, however, we may well get a (mitigated) fall of the relative wage associated with increasing import penetration and falling employment. All of which only serves to illustrate the point that bivariate correlations are hard to interpret if various exogenous forces can vary at the same time.

The non-neutral technical change just mentioned is in fact the most-cited alternative to globalization as a cause of the deteriorating labor market position of unskilled workers. That it must be an important factor - in fact, a more important factor than globalization - has been argued by Krugman and Lawrence (1994) on the basis of yet another simple observation. If globalization caused the rising skill premium on the US labor market along the lines of the HOS model, the corollaries of the implied chain of transmission should also be observable. According to that model, as the relative price of skilled labor rises due to the forces of globalization, one should see the skill-intensity of production fall across industries as producers turn towards the factor which is getting cheaper. But in fact, the skill-intensity of production has strongly risen in the USA across the board, even in the nontradables sector, and in spite of the rising relative price of skilled labor. One is thus forced to conclude that factor demand functions have shifted for technological reasons. Whether the terms of trade have turned against import competing sectors as the HOS-globalization story would also imply, is a hotly disputed matter. The evidence on goods prices is hard to read because of numerous measurement problems. ${ }^{24}$

Apart from the obvious importance and likely non-neutrality of technological change, the most persuasive evidence against the globalization hypothesis is related to the volume of North-South trade which, despite its growth in recent years, is indeed very small compared to the size of the North - below $2 \%$ of the combined GDP of all industrial economies (cf. Krugman 1995). The significance of such figures has been questioned on the grounds that the relevant variable on which all further effects depend is relative prices, not volumes. But of course, from a general equilibrium perspective, even if it is as simple as the one in figure

\footnotetext{
${ }^{24}$ On this issue, see the studies in Part II of the Collins (1998) volume.
} 
4, above, prices and quantities are jointly determined by exogenous forces acting through supply or demand. And simulations of calibrated general equilibrium models such as those by Krugman (1995) and Cline (1997) find it hard to attribute a major part of observed wage and employment changes to globalization.

If there is anything like a conventional wisdom regarding the effects of globalization on wages and unemployment, it can thus be characterized as saying that globalization is an indisputable force which makes itself felt on the labor markets of the advanced industrial economies, but that it cannot account for more than a minor part of the shifts in the wage distribution or of the increase in unemployment. Slaughter and Swagel (1997) dare to put a summary figure on this conventional wisdom and speak of 10-20 percent of the changes in wages and income distribution in the advanced economies that are due to imports from developing countries. The impact on unemployment in the rigid European economies could be somewhat larger. ${ }^{25}$

It may nevertheless be too early to conclude with reasonable confidence that this conventional wisdom is correct. Research has begun increasingly to explore effects and mechanisms that are beyond the reach of the simple trade models which have largely dominated the literature so far. The findings do not all point the same way, but they open up new perspectives and lead to sometimes surprising insights. An interesting point in case is the trade in intermediates that has resulted from the fragmentation of the value chain as a consequence of low transportation costs and efficient information processing. Of course, such trade has long been recognized as an important aspect of globalization. The ease with which various parts of the production chain can be moved from one place to another introduces considerable instability into factor markets and increases the demands that are placed on the flexibility of workers and markets.

Apart from the volatility issue, however, the 'footloose' character of globalized production processes also suggests a different assessment of the relative labor market effects of trade and technology. Feenstra (1998), in particular, argues that existing studies could be seriously biased against the quantitative importance of trade by their neglect of trade in intermediates. The point is very simple: If outsourcing is most likely to affect the least skill-intensive activities, the average skill-intensity of production must rise regardless of changes in the skill-intensity of those activities that remain. Therefore, as Feenstra puts it, "globalization has an impact on employment and wages that is observationally equivalent to the

${ }^{25}$ Bhagwati (1998) sharply criticizes such estimates that result from averaging the available empirical studies since this procedure ignores "the fact that, in science, the average of good and bad is bad." His own estimate is an outlier in that he argues that globalization has actually favored labor-intensive manufacturing industries in the North. 
changes induced by technological innovation." ${ }^{26}$ This compositional effect is similar in spirit to the one invoked above to explain the US-European differential with respect to average productivity growth in the service sector.

The significance of Feenstra's point extends far beyond the specifics of quantifying the impact of globalization. What it does on a more fundamental level is to demonstrate the conceptual difficulty of trying to discriminate between technological shocks and globalization in the first place. Time and again, authors contributing to the debate on trade and wages have observed that technological innovations have fostered globalization and that globalization in turn facilitates the development and diffusion of new technologies. Nevertheless, the literature has gone on debating the relative importance of globalization and technology as if economists did not learn early in their careers that there are only two truly exogenous forces in economics: tastes and technology. In fact, as classical trade theory has always emphasized, trade is just another technology for turning resources into the goods consumers value most. It is indeed no accident that the effects of technological progress and expanding trade are similar in many respects and that they encounter much the same sort of resistance along the way.

\section{Summary and Conclusion}

This paper has considered three conventional wisdoms concerning the relationships between wages, unemployment and globalization:

1. It is widely believed that economies face a trade-off between real wage growth and unemployment. The United States, it appears, has opted for high employment growth and low real wage growth whereas most European countries, by the design of their labor market institutions and policies, have chosen the opposite. This view needs to be qualified: A high-wage policy cannot, in the long run, raise the productivity of jobs, but it can influence the composition of the jobs that are viable and thereby affect the aggregate picture.

2. Another conventional wisdom maintains that the shift of labor demand towards high skills has created a trade-off between wage inequality and unemployment. If labor markets are flexible (and if the demand shift dominates any shifts in relative supplies that may occur at the same time), the wage differential between skilled and unskilled labor widens, which is what happened on the US labor market. If relative wages are rigid, in

${ }^{26}$ Feenstra (1998), p. 32 (italics in the original). The interdependence of technology and globalization that arises through the fragmentation of the production process is also emphasized by Burda/Dluhosch (1998) and Deardorff (1998). 
contrast, which is largely the case in most continental European economies, the demand shift leads to an increase in unskilled unemployment. This proposition is built on theoretically more robust ground than the first. But this does not mean that relative demand shifts are the dominant force behind European unemployment, nor is the empirical picture quite as sharp as one might expect. The correlation between measures of relative wage rigidity and the unemployment rates of unskilled labor is somewhat fuzzy. This is not entirely surprising once it is recognized that skilled labor can be adversely affected even if labor demand shocks are biased against unskilled labor (cf. Burda/Dluhosch 1998), and that unskilled labor is disproportionately affected even by aggregate labor demand shocks (cf. Blanchard 1997b).

3. A third proposition concerns the role of globalization. According to widely held views, often reinforced by the popular press and the infotainment industry, globalization is a major cause of labor market problems in general and of the deteriorating situation of the less-skilled in particular. Mainstream academic research does not support this view so far. The volume of NorthSouth trade is simply too small for competitive pressures from low-wage imports to become a major cause of labor market disruptions in the North. Instead, non-neutral technological change is seen as the main driving force behind the structural changes on the demand side of the labor market. But it would certainly be premature to regard the issue as resolved. As channels of causation are considered that lie outside the focus of traditional HOS models of trade, the case for a major impact of globalization appears to grow stronger. On a more fundamental level, recent work questions the separability of technological change and globalization.

Globalization is not an entirely new phenomenon. Recent historical research has uncovered many parallels between today's globalized economy and the world economy of the late 19th century. Distributional effects were a serious concern then as much as today. According to Williamson (1998), they contributed to the backlash against globalization which eventually caused the world to drift away from its previous liberal international order. As we know today, the real threat to jobs, wages and economic prosperity did not originate from globalization, but from the backlash against it. That is why the current widespread obsession with globalization as a threat to jobs and wages is fundamentally misplaced. But for the very same reason, it must be taken seriously.

Of course, globalization also means that far-away events can sometimes have adverse effects on individuals, businesses and entire economies. The oil price shocks of the 1970s were a reminder of this obvious truth. They also exposed the labor market rigidities that are the subject of conventional wisdom No. 1, above. But at the same time, globalization is just one of the many forces that make for permanent structural change. And as Schumpeter has famously remarked, such change involves a fair amount of 'creative destruction', which includes the destruction of existing jobs. The challenge is to make sure that the destruction is in fact creative, i.e. that there are no impediments to the creation of new jobs. This is 
a general challenge to the design of the economic order and labor market institutions, not a challenge posed by globalization in particular.

Whether or not the forces that generate a trade-off between inequality and unemployment are the dominant causes of the European unemployment problem, they demonstrate how labor market institutions that are designed to protect the stakes of job holders reduce the adjustment capacity of the system as a whole and thereby reveal the essence of the underlying labor market malfunctioning. On the political level, therefore, the challenge is to redesign the social safety measures for the losers of the creative destruction process so as to minimize their interference with the allocation function of the labor market. There is no lack of promising ideas. But these are beyond the scope of this paper. ${ }^{27}$

${ }^{27}$ The issue of labor market policies is taken up by Berthold/Fehn (1999, in this volume). 


\section{References}

Bean, Ch. (1989), Capital Shortages and Persistent Unemployment, Economic Policy 8, 12-53.

Berthold, N. and R. Fehn (1999), Labor Market Policy in a Global Economy, in this volume.

Bhagwati, J. (1998), Play it Again, Sam: A New Look at Trade and Wages, mimeo, Columbia University.

Blanchard, O. (1990), Unemployment: Getting the Questions Right - and Some of the Answers, in: Drèze, J. and Ch. Bean (eds.), Europe's Unemployment Problem, Cambridge, 66-89.

Blanchard, O. (1997a), The Medium Run, Brookings Papers on Economic Activity 2, 89-141.

Blanchard, O. (1997b), Macroeconomic and Policy Implications of Shifts in the Relative Demand for Skills, in: Snower, D. and G. de la Dehesa (eds.), Unemployment Policy, Cambridge, 282-290.

Brecher, R. (1974a), Optimal Commercial Policy for a Minimum-Wage Economy, Journal of International Economics 4, 139-149.

Brecher, R. (1974b), Minimum Wage Rates and the Pure Theory of International Trade, Quarterly Journal of Economics 88, 98-116.

Bruno, M. and J. Sachs (1985), Economics of Worldwide Stagflation, Cambridge.

Burda, M. (1988), Is There a Capital Shortage in Europe?, Weltwirtschaftliches Archiv 124, 38-57.

Burda, M. and B. Dluhosch (1998), Globalization and European Labor Markets, CEPR Discussion Paper No. 1992, London.

Burtless, G. et al. (1998), Globaphobia, Washington, D.C.

Caballero, R. and M. Hammour (1997), Jobless Growth: Appropriability, Factor Substitution, and Unemployment, NBER Working Paper 6221, October.

Cline, W (1997), Trade and Income Distribution, Washington.

Collins, S. (1998), Imports, Exports, and the American Worker, Washington, D.C. 
Corrado, C. and L. Slifman (1999), Decomposition of Productivity and Unit Costs, American Economic Review 89(2), P.P.,328-332.

Deardorff, A. (1998), Fragmentation in Simple Trade Models, mimeo, University of Michigan.

Drèze, J. and H. Sneesens (1997), Technological Development, Competition from Low-Wage Economies, and Low-Skilled Unemployment, in: Snower, D. and G. de la Dehesa (eds.), Unemployment Policy, Cambridge, 250-277.

Feenstra, R. (1998), Integration of Trade and Disintegration of Production in the Global Economy, Journal of Economic Perspectives 12(4), 31-50.

Freeman, R. and L. Katz (1995), Differences and Changes in Wage Structures, Chicago.

Gordon, R.J. (1997), Is There a Trade-Off Between Unemployment and Productivity Growth, in: Snower, D. and G. de la Dehesa (eds.), Unemployment Policy, Cambridrge, 433-463.

Hesse, H. (1998), Comment on Landmann and Pflüger, in Gahlen, B. et al. (eds.), Verteilungsprobleme der Gegenwart, Tübingen, 159-167.

IMF (1995), World Economic Outlook, May.

IMF (1997), World Economic Outlook, May.

Krugman, P. (1994), Past and Prospective Causes of High Unemployment, in: Reducing Unemployment: Current Issues and Policy Options. A Symposium Sponsored by The Federal Reserve Bank of Kansas City, Jackson Hole, 49-98.

Krugman, P. (1995), Growing World Trade: Causes and Consequences, Brookings Papers on Economic Activity 1, 327-362.

Krugman, P. and R. Lawrence (1994), Trade, Jobs and Wages, Scientific American, April, 44-49.

Landmann, O. and J. Jerger (1993), Unemployment and the Real Wage Gap: A Reappraisal of the German Experience, Weltwirtschaftliches Archiv 129, 689717.

Landmann, O. and J. Jerger (1999), Beschäftigungstheorie, Heidelberg-Berlin.

Landmann, O. and M. Pflüger (1996), Arbeitsmärkte im Spannungsfeld von Globalisierung und technologischem Wandel, in B. Külp (ed.): Arbeitsmarkt und Arbeitslosigkeit, Freiburg, 173-230. 
Landmann, O. and M. Pflüger (1998), Verteilungswirkungen der Globalisierung, in Gahlen, B. et al. (eds.), Verteilungsprobleme der Gegenwart, Tübingen, 127-157.

Lucas, R. E. (1988), On the Mechanics of Economic Development, Journal of Monetary Economics 22, 3-42.

Mankiw, N. G., D. Romer, and D. Weil (1992), A Contribution to the Empirics of Growth, Quarterly Journal of Economics 107, 407-437.

Malinvaud, E. (1977), The Theory of Unemployment Reconsidered, Oxford.

Nickell, S. and B. Bell (1995), The Collapse in Demand for the Unskilled and Unemployment Across the OECD, Oxford Review of Economic Policy 11, 4062.

Ochel, W. (1998), Mehr Beschäftigung und weniger Arbeitslosigkeit - Amerika, hast du es besser?, Mitteilungeen aus der Arbeitsmarkt- und Berufsforschung 2, 262-276.

Phelps, E.S. (1994), Structural Slumps, Cambridge.

Phelps, E.S. (1997), Quids in if you work, Financial Times, October 31.

Sachs, J. (1979), Wages, Profits, and Macroeconomic Activity: A Comparative Study, Brookings Papers on Economic Activity 2, 269-319.

Siebert, H. (forthcoming), Globalization and Labour, Tübingen.

Srinivasan, T.N. (1995), Comment on Krugman, Brookings Papers on Economic Activity 1, 368-373.

Slaughter, M. and Ph. Swagel (1997), The Effect of Globalization on Wages in the Advanced Economies, IMF Working Paper 97/43.

Williamson, J. (1998), Globalization, Labor Markets and Policy Backlash in the Past, Journal of Economic Perspectives 12(4), 51-72.

Wood, A. (1991), Give Heckscher and Ohlin a Chance!, Weltwirtschaftliches Archiv 127, 20-49.

Wood, A. (1995), How trade hurt unskilled workers, Journal of Economic Perspectives 9(3), 57-80.

World Bank (1997), Global Economic Prospects and the Developing Countries, Washington, D.C. 